\title{
Mechanochemical Phenomena during Fine Comminution of Clay Minerals for Ceramic Bricks and Roof-Tiles
}

\author{
László A. Gömze \\ ${ }^{1}$ Department of Ceramics and Silicate Engineering, University of Miskolc, Hungary \\ afemgomze@uni-miskolc.hu;
}

Keywords: clay minerals, grinding, layered silicates, mechanochemistry, milling, phase transformation.

\begin{abstract}
During the fine comminution of clay minerals and layered silicate materials with relative large volume of specific surface area appreciable changes in chemical and minerological compositions can be observed. In this paper is described the mechanochemical investigation of conventional clay minerals from „Lenti” region (Hungary), having natural BET specific surface larger than 35-40 square metres per grams. The laboratory experiments made by author had shown an intensive reduction of specific surface volume at the beginning of grinding, further relatively slow growth and reduction of BET and Langmuir surfaces were observed. The content of mineral Muscovite-2M1 - $(\mathrm{K}, \mathrm{NH} 4 \mathrm{Na}) \mathrm{A} 12(\mathrm{SiAl}) 4 \mathrm{O} 10(\mathrm{OH}) 2$ - has decreased and the contents of Quartz $\mathrm{SiO} 2$ - and Illite-1M (NR) - KO.7A12(SiAl)4O10 $(\mathrm{OH}) 2$ - have increased considerable depending on grinding time. Increasing the milling time the amount of Albite - NaAlO.91Si3O8 - and other mineral components were also not stable, but their content have varied not so strong as Muscovite$2 \mathrm{M} 1$ or Quartz and Illite-1M. The examined clay minerals had a certain proportion of amorphous particles as well, but in this contribution only the changes in proportions of crystalline particles are described.
\end{abstract}

\section{Introduction}

To decrease the particle sizes and increase the specific surface area of materials is one of the most energy-intensive technological processes [1, 2]. Already in 1974 [3] and in 1980 [4] were shown, how the required energy of crushing and grinding was dependent on both of used equipment and the physico-mechanical properties of ground materials. In the ceramic facing-brick and roof-tile industry the reduction of particle sizes is one of the most energy-intensive technological processes not only because of the used equipment and physico-mechanical properties of milled materials, but of the mechanochemical phenomena taking place during fine comminution.

Changes in chemical composition of materials occurring during fine grinding were observed and published first already in 1894. [5] and the term of „mechano-chemistry” in 1919 [6]. In spite of these early two works, the transformation and changes in chemical composition of materials occurring through the action of mechanical energy as „mechanochemical reactions" were interpreted first only in 1962 [7]. In Hungary the first publications on mechanochemistry were appeared in the late of the sixties and were mainly based in works of Juhász $[8,9,10]$ and Opoczky $[11,12,13]$. Later considerable works were published by Péter [14, 15].

At present it is obvious the surface sizes, structures, activities and the internal chemical and crystal composition of materials can be modified by a controlled mechanical activation process [16-23]

\section{Materials and experimental procedures}

Nowadays, ceramic items are normally produced with materials having submicron and nanoparticles [24-28]. The raw materials mined at the European ceramic brick and roof-tile plants usually contain considerable proportions of clay minerals, phyllosilicates, layered and amorphous silicate materials [29-34], and have submicron particles in different ratios with different specific 
surface area and grain size distribution. In extrusion and forming process of frost-resistant ceramic facing bricks and roof-tiles the used raw materials usually have a large volume of particles with grain sizes less than $300 \mathrm{~nm}[29,35]$. Because of these, in the most of ceramic plants additional grinding and fine comminution are required [29, 33, 35]. To understand the effect of mechanical activation on the physico-chemical, mineralogical and technological properties of clay minerals conventional brick clay from region Lenti (Hungary) was examined. The „Lenti-clay” has a complex mineralogical composition of which the mechanical activations were made on laboratory pan grinder (Fig. 1.). Using pan grinder the volumes of mechanical energy are turned on development of crushing pressures and shear stresses in ground material can be determined by mathematical equations of [36].

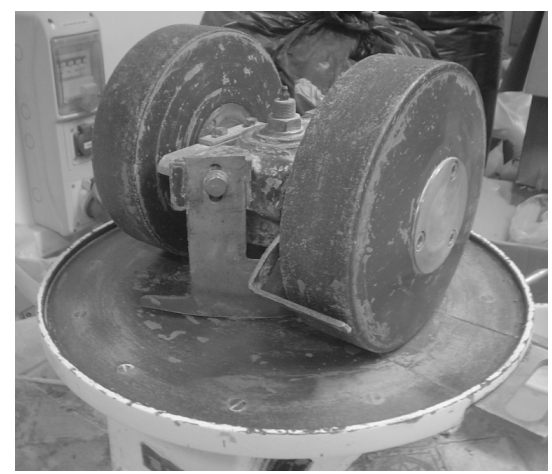

Fig. 1. The used laboratory pan grinder without vessel

In the laboratory tests of mechanical activation through grinding both wet and dry „Lenti clays” (Hungary) were used. The wet clays had their original mined moistures and the dry clays were dried through 48 hours at temperature of $95{ }^{\circ} \mathrm{C}$ in a chamber drier. The samples were taken of 2 kilograms for each experiment and were ground both in wet and dried versions. The grinding times were changed from 10 minutes up to 30 hours. The grinding processes were started and continued in an „open” laboratory with a room temperature about of $25{ }^{\circ} \mathrm{C}$. During comminution by 5 -times 20 grams specimens were taken from laboratory pan grinder vessel after 10, 20, 30, 40, 60, 90, 120, 180, 360, 1080, 1440 and 1800 minutes as representative samples, and examined on specific surface and mineralogical compositions.

To evaluate the efficiency of mechanical activations and mechanochemical processes TriStar 3000 specific surface tester and Bruker D8-Advance XRD were used. The ,average” mineralogical composition of the conventional Lenti clay determined by X-ray powder diffraction (XPD) is shown in Table 1.

Table 1. Mineralogical composition of Lenti clay (Hungary) before grinding

\begin{tabular}{|l|l|c|}
\hline \multicolumn{1}{|c|}{ Mineral } & \multicolumn{1}{|c|}{ Chemical Formula } & Quantity [\%] \\
\hline Quartz, low syn & $\mathrm{SiO} 2$ & 31.00 \\
\hline $\begin{array}{l}\text { Chlinochlore, Iib-2 (Cr-bearing, } \\
\text { dehydrated) }\end{array}$ & $\mathrm{Mg} 3(\mathrm{Mg} 2 \mathrm{Al})((\mathrm{Si} 3 \mathrm{Al}) \mathrm{O} 10)(\mathrm{OH}) 2 \mathrm{O} 3$ & 8.90 \\
\hline Palygorskite M & $\mathrm{Mg} 5(\mathrm{Si} 4 \mathrm{O} 10) 2(\mathrm{OH}) 2(\mathrm{H} 2 \mathrm{O}) 8$ & 7.00 \\
\hline Muscovite-2M1, ammonian & $\mathrm{K}(\mathrm{NH} 4, \mathrm{Na}) \mathrm{Al} 2(\mathrm{Si}, \mathrm{Al}) 4 \mathrm{O} 10(\mathrm{OH}) 2$ & 36.60 \\
\hline Phillipsite-K & $(\mathrm{K}, \mathrm{Na}) 2(\mathrm{Si}, \mathrm{Al}) 8 \mathrm{O} 16 * 4 \mathrm{H} 2 \mathrm{O}$ & 9.0 \\
\hline Illite-1M $(\mathrm{NR})$ & $\mathrm{K} 0.7 \mathrm{~A} 12(\mathrm{Si}, \mathrm{Al}) 4 \mathrm{O} 10(\mathrm{OH}) 2$ & 1.40 \\
\hline Albite, $(\mathrm{low})$ & $\mathrm{Na}, \mathrm{A} 10.91 \mathrm{Si} 3 \mathrm{O} 8$ & 5.80 \\
\hline
\end{tabular}

During the XPD examination Bragg-Bentano geometry and $\mathrm{Cu}-\mathrm{k} \alpha$ rays were used in angular interval of $4^{\circ}-60^{\circ}$ with steps of 20 and $0.06^{\circ}$. Data collection times were of 2 seconds per steps. The evaluation was made with EVA software of Bruker DiffracPlus software Package. The phases were 
determined by Search/Match method using powder diffraction data base file PDF2. The quantitative analysis of determined mineral compositions was made with software EVA Fullpattern Matching (FPM).

To determine the average BET and Langmuir specific surfaces and the proportions of mineralogical composition each experiment and measurement were repeated by 5 times.

\section{Results and discussion}

During fine comminution of conventional brick clays on pan grinders several factors influence on the mechanical activation and mechanochemical processes. Some of the most important from them are the followings:

- Chemical and mineralogical composition of ground material;

- Crystal structure and lattice parameter of mineral components;

- Volumes and values of stresses developed in material particles during grinding;

- Interatomic bonding forces on surfaces and inside of ground particles;

- Grinding times and temperatures.

The theoretical curve of developed specific surface as function of grinding time [37] is shown in Fig. 2.

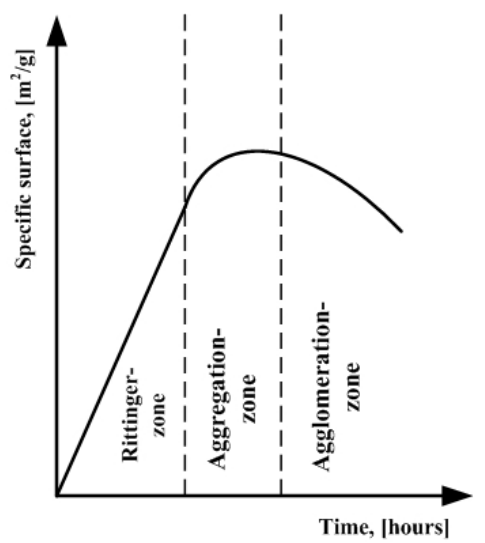

Fig. 2. Theoretical curve of specific surface as function of grinding time.

On this theoretical curve 3 well separated zones can be observed. Those are:

- Rittinger-zone: growth of specific surface is proportionate to grinding time;

- Aggregation-zone: intensity of specific surface growth is decreasing by grinding time;

- Agglomeration-zone: the specific surface is decreasing by comminution time.

The BET and Langmuir specific surfaces achieved during fine comminution of conventional Lenti clays (Hungary) on laboratory pan grinder (Fig. 3.) are quit different, than theoretical.

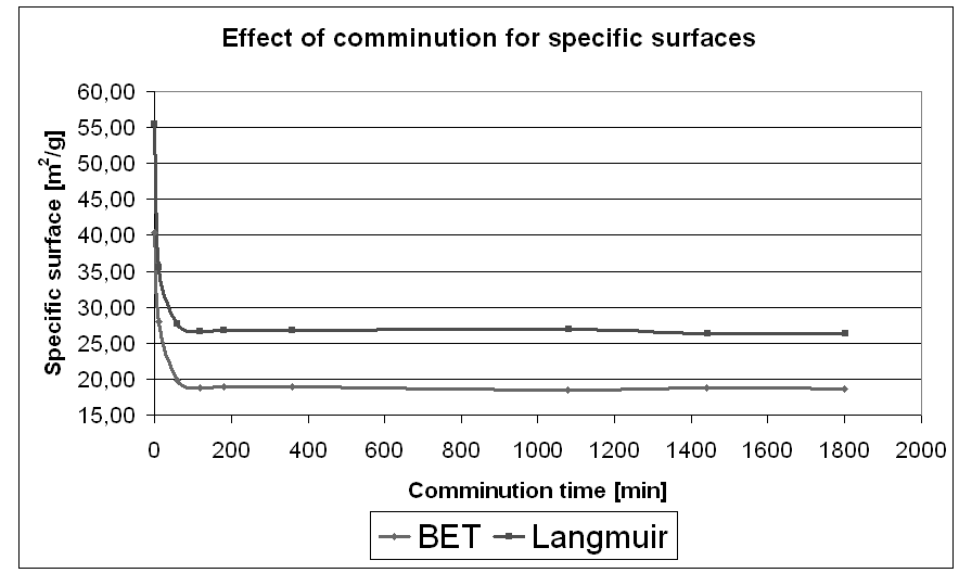

Fig. 3. The BET and Langmuir specific surfaces of Lenti clays (Hungary) as function of grinding time. 
Instead of growth both BET and Langmuir specific surfaces have decreased very intensively in the first 30 minutes of grinding. After 60 minutes the specific surface reduction diminished considerable and after 120 minutes of comminution there were no remarkable changes in specific surfaces. On the other hand, the quantitative analysis of XPD patterns made by software EVA FPM showed radical changes in mineralogical composition (Fig. 4.), took place up to 1440 minutes of grinding.

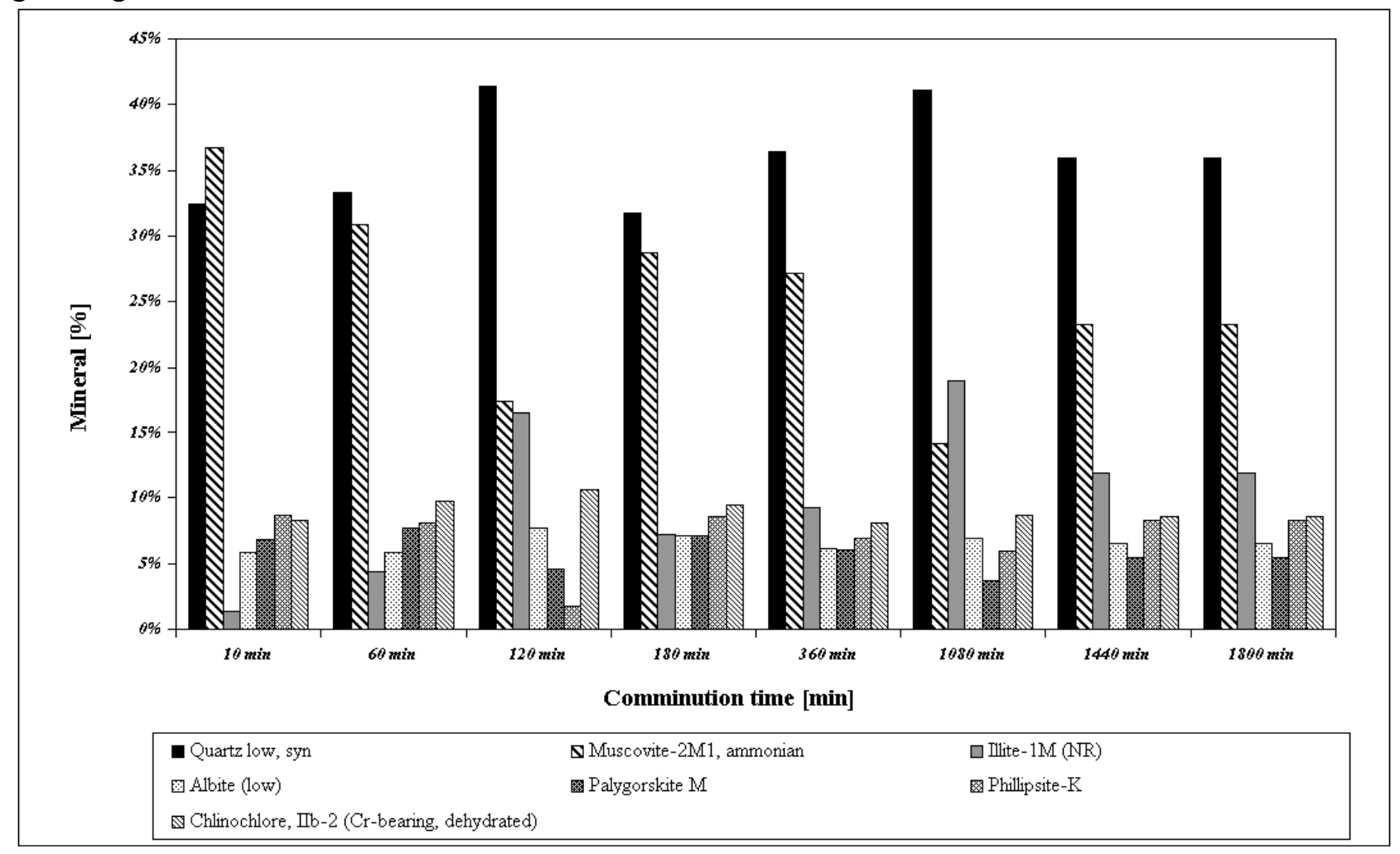

Fig. 4. Changes in mineralogical composition of dried Lenti clays (Hungary) during comminution on laboratory pan grinder

The proportions of all mineralogical components of conventional Lenti clays are changed in dependence on grinding time. The most intensive mechanochemical processes and dramatically changes can be observed in mineral component of Muscovite-2M1 through its dissociation and transformation into Illite-1M, Quartz and others. After 60 minutes of grinding the content of Muscovite-2M1 - (K,NH4,Na)Al2(SiAl)4O10 $(\mathrm{OH}) 2$ - decreased from $36.6 \%$ to $30.9 \%$, meanwhile the amount of Quartz - $\mathrm{SiO} 2$ - grew from $31 \%$ to $33.3 \%$ and Illite-1M - (NR) $\mathrm{K} 0.7 \mathrm{Al} 2(\mathrm{SiAl}) 4 \mathrm{O} 10(\mathrm{OH}) 2$ - from $1.4 \%$ to $4.4 \%$. Opposite to specific surfaces, in mineralogical composition the considerable changes were continued up to 1440 minutes of grinding. At 1080 minutes of comminution of Lenti clay the content of Muscovite-2M1 has obtained its minimum value of $14,1 \%$, meanwhile the amount of Illite-1M (NR) increased up to $19.1 \%$ and Quartz up to $41.6 \%$.

During the grinding of Lenti clay (Hungary) on laboratory pan grinder the proportion and content of the other mineralogical components, like Chlinochlore 11b-2, Paligorskite M, Phillipsite$\mathrm{K}$ and Albite (low) have changed also, but not so intensively and strong, as Muscovite-2M1, Illite$1 \mathrm{M}$ and Quartz.

\section{Conclusions}

On the basis of realized grinding experiments on clay minerals of ceramic brick and roof tile industry, mined in region "Lenti" (Hungary) the following conclusions can be made:

- At the conventional clay minerals having natural BET and Langmuir specific surfaces larger than (35-40) $\mathrm{m}^{2} /$ gram, instead of surface growth intensive surface reduction can be observed 
in the first 60 minutes of their mechanical activation on laboratory pan grinder, because of the strong agglomeration of their particles.

- During fine comminution of clay minerals and layered silicates with complex mineralogical composition, like Lenti clay (Hungary), the most intensive mechanochemical processes and dramatically changes can be observed in mineral component of Muscovite-2M1 $(\mathrm{K}, \mathrm{NH} 4, \mathrm{Na}) \mathrm{Al} 2(\mathrm{SiAl}) 4 \mathrm{O} 10(\mathrm{OH}) 2$ - because of its dissociation and transformation into minerals, like Illite-1M, Quartz, Albite and others.

- Using controlled mechanical activation not only the surface sizes, structures and activity, but the internal chemical and mineral structures and compositions can be modified at brick clays with complex mineralogical composition, like Lenti clay. The controlled mechanical activation of raw materials before forming especially important during production of frostresistant facing bricks and ceramic roof tiles.

\section{Acknowledgements}

The author would like to thank to Wienerberger, Tondach and Creaton Groups for financial support the mechanochemical research in several years, and to colleagues and $\mathrm{PhD}$ students at Department of Ceramics and Silicate Engineering, University of Miskolc (Hungary). The author is especially grateful to Professor Giovanni Valdre for some fundamental remarks and comments.

\section{References}

[1] B. Beke: Principles in Comminution, Academy Press, Budapest (1963)

[2] M. Ya. Sapozhnikov: Mehanitseskoe oborudovanie; Izdatel'stvo, Visshaya Shkola, Moscow (1971)

[3] L. A. Gomze, A. V. Turenko and A. Nazarov: Epitoanyag, Vol. 26 (1974), p. 348.

[4] L. A. Gomze: Epitoanyag, Vol. 32 (1980), p. 385.

[5] M. L. Carey: Phil. Mag. Vol. 37 (1894), p. 470.

[6] W. Ostwald: Handbook der allgemeinen Chemie, Akad. Verlangsanstalt, Lepizig (1919)

[7] K. I. Peters, in: European Symposium Zerkleinern, edited by H. Rumpf, Verlag Chemie, VDI Verlag, Dusseldorf (1962)

[8] Z. Juhasz: Epitoanyag Vol. 17 (1965), p. 419.

[9] Z. Juhasz: PhD Thesis, Academy Press, Budapest (1969)

[10] Z. Juhasz, M. Timár and Z. Adamis: Epitoanyag vol. 29. (1977), p. 327.

[11] L. Opoczky: Epitoanyag Vol. 18 (1966), p. 41.

[12] L. Opoczky: Epitoanyag Vol. 21 (1969), p. 188.

[13] L. Opoczky: Epitoanyag Vol 34 (1982), p. 441.

[14] L. Pentek: Epitoanyag Vol. 28 (1976), p. 452.

[15] L. Pentek, S. Verdes: Epitoanyag Vol. 38 (1986), p. 305.

[16] L. Opoczky, F. Farnady: Powder Technology Vol. 39 (1984), p. 107.

[17] Z. Juhasz, I. Wojnarovits: Ceramic Forum International Vol. 61 (1984), p. 131

[18] S. Yariv, I. Lapides: Journal of Materials Synthesis and Processing Vol. 8 (2000), p. 223.

[19] P. K. Panigraphy, G. Goswani, J. D. Panda and R. K. Panda: Cement and Concrete Research vol. 33 (2003), p. 945.

[20] M. C. Santos, A.R.A. Nagueira and J. A. Nogrega: Journal of the Brazilian Chemical Society Vol. 16 (2005), p. 108.

[21] F. Dellisanti, G. Valdre: Applied Clay Science Vol. 38 (2005), p. 233.

[22] F. Dellisanti, G. Valdre: International Journal of Mineral Processing Vol. 88 (2008), Issues 3-4, p. 94.

[23] F. Dellisanti, G. Valdre, M. Mondonico: Applied Clay Science Vol. 42 (2009), p. 398.

[24] S. N. Kulkov, N. L. Savchenko: Epitoanyag vol. 60 (2008), p. 62.

[25] A. Morikawa, T.Suzuki, K. Kikuta, A. Suda and H. Shinjo: Epitoanyag Vol. 61 (2009), p. 2. 
[26] N.I. Ershova, I. Yu. Kelina: Epitoanyag Vol. 61 (2009), p 34.

[27] L. A. Gomze, L. N. Gomze: Epitoanyag Vol. 61 (2009), p 38.

[28] K. Katahira, H. Ohmori: Epitoanyag Vol. 61 (2009), p. 114.

[29] K. Junge, A. Tretau and E. Specht, in. Annual for the Brick and Tile, Structural Ceramics and Clay Pipe Industries; edited by W. Muller and A. Fischer, Bauverlag BV GmbH, Gutersloh (2008)

[30] L. A. Gomze, L. N. Gomze: Epitoanyag Vol. 60 (2008), p 102.

[31] K. Toth, P. Balint and J. Bakos: Epitoanyag Vol. 20 (1968), p 302.

[32] P. Balint, B. Szöke, J. Juhasz and T. Skorecz: Ceramics International Vol. 7 (1981), p. 35.

[33] G. P. Emilian, E. Corbara: Technologia ceramica le materie prime, Vol. 1. OSBN 88-8138043-9, Italy (2001)

[34] A. I. Rabuhin, V. G. Saveliev: Fizitseskaya himiya tugoplavkih nemetalitseskih i silikatnih soedinenij, Infra-M publisher, Moscow (2004)

[35] F. Handle at all: Extrusion in Ceramics, Springer Verlag, Berlin-heidelberg (2007)

[36] L. A. Gomze: Epitoanyag Vol. 56 (2004), p. 93.

[37] Z. A. Juhasz, L. Opoczky: Mechanical Activation of Minerals by Grinding, Pulverizing and Morphology of Particles, Ellis Horwood Ltd. Publisher, West Sussex, England (1990) 